\title{
Paremäärmuslikud kajakambrid ja autokommunikatsioon ${ }^{1}$
}

\author{
Mari-Liis Madisson \\ Tartu Ülikooli filosoofia ja semiootika instituudi semiootika teadur, \\ ühiskonnateaduste instituudi kultuurikommunikatsiooni nooremteadur \\ ml.madisson@gmail.com \\ Andreas Ventsel \\ Tartu Ülikooli filosoofia ja semiootika instituudi semiootika vanemteadur \\ andreas.ventsel@gmail.com
}

\begin{abstract}
Teesid: Analüüsime käesolevas artiklis paremäärmuslikku eestikeelset veebisuhtlust, mida iseloomustab kajakambri efekt ja suletusele orienteeritud hermeetiline tähendusloome. Teoreetilises plaanis lähtume ennekõike Tartu-Moskva kultuurisemiootika raamistikust. Eristame antiteesil tuginevat tähendusloomet "õigete" tekstide kogumile suunatust ning faatilise funktsiooni domineerimist kui dominantseid tunnuseid, mille esinemise korral suubub suhtlemine suletud ja stambistunud autokommunikatsiooni. Niisugune kommunikatsioon toob kaasa ühiskondliku avaliku kommunikatsiooniruumi polariseerumise ja dialoogist kaugenemise. Juhtumiuuringuna analüüsime diskussiooni, mis kerkis esile 2015. aasta kevadel seoses massilise põgenike sisserändega Euroopasse.
\end{abstract}

Märksõnad: autokommunikatsioon, eesti paremradikaalne online-suhtlus, faatiline kommunikatsioon, kajakambri efekt, kultuurisemiootika, 2015. aasta põgenikekriis

Ülemaailmne arvutivõrk annab indiviidile pretsedenditu võimaluse valida erinevate info- ja kommunikatsiooniressursside vahel ning panna kokku oma huvidele vastav tähenduspakett. Plahvatuslikult on kasvanud juurdepääs erinevatele institutsionaalsetele, aga ka vernakulaarsetele infoallikatele ja nende hübriidvormidele. Ühelt poolt tagab kanalite mitmekesistumine ligipääsu võimalikult erinevatele vaatepunktidele ja sõnumi konstrueerimise tavadele (Downey \& Fenston 2003: 194; Chadwick 2009), ent teisalt loob see kasvulava võrdlemisi homogeensete interaktsioonide tekkeks. Mitmed uurijad toovad välja, et tänapäevase n-ö rohujuuretasandi meedia kontekstis kerkib esile valikulise kokkupuute (selective exposure) fenomen. Nimelt annab online-sfäär 
indiviididele võimaluse liikuda suhteliselt hermeetilises tähendusruumis, mis hoiab võrdlemisi harvana kokkupuuted põhimõtteliselt teistlaadi ideede või koguni kimbatust ja vastuolulisust esile kutsuvate mõtteavaldustega (Grömping 2014: 44; Stroud 2010: 556; Sunstein 2009: 80).

Folklorist ja meediauurija Robert Glenn Howard on konkreetsete veebilehekülgede ümber koondunud n-ö rohujuuretasandi võrgustike selgitamiseks kasutusele võtnud vernakulaarse veebi mõiste. Howardi järgi on vernakulaarse veebi üks oluline karakteristik seal vahetatud ideede baseerumine suuresti juba olemasolevatel või vähemasti osalejate silmis aktsepteeritavatel väärtustel. Kusjuures ühised hoiakud muutuvad vernakulaarsetes veebides aja jooksul koherentsemaks ja püsivamaks (Howard 2013: 82; 2008). On üsna tõenäoline, et isegi väga eripäraste vaadetega indiviidid leiavad "õigeid" otsingusõnu kasutades küllaltki hõlpsasti sobiva vernakulaarse kogukonna, kellega neil oleks offline-maailmas veendumuste marginaalsuse tõttu võib-olla keeruline kokku puutuda (vt Sunstein 2009: 81; Wojcieszak 2010: 641). Paljud vernakulaarsete online-kogukondade arvamuskliimat ja dünaamikat käsitlevad uurimused on jõudnud muret tekitava järelduseni, et sealset suhtlust iseloomustab kajakambri efekt: väga sarnaste vestluspartneritega suheldes eelarvamused ja ühised seisukohad kinnistuvad ja polariseeruvad (vt Grömping 2014; Kushin \& Kitchener 2009; Stroud 2010; Van Alstyne \& Brynjolfsson 2005; Sunstein 2009). Kajakambrite mõjuväljas olnud indiviidid kipuvad valdavalt genereerima ja aktsepteerima põhjuslikkust, mis nende vaateid õigustab. Infosse, mis olemasolevatest arusaamadest lahkneb, suhtutakse kui mitte süvenemist väärivasse või vähemasti umbusku tekitavasse (Wojcieszak 2010: 649).

Käesolev artikkel läheneb kajakambri probleemile, uurides eesti paremäärmuslaste vernakulaarset online-suhtlust, mida on seni käsitlenud võrdlemisi vähesed tööd (Madisson \& Ventsel 2014; 2015; Siibak 2012; 2014; vt ka Jakobson et al. 2012). Paljud paremäärmuslike n-ö rohujuuretasandi kogukondi ja nende arengut käsitlevad uurimused on toonud välja, et seal on oluliseks suundumuseks suletud ja polariseeruvate interaktsioonide esiletõus (Askanius \& Mylonas 2015; Hirvonen 2013; Wojcieszak 2010). Sellele on osutatud näiteks kui informatsioonilisele kookonile, mis välistab sinna sissejääjate puhul igasuguse reaalsustesti (Griffin 2011: 69); umbkogukondadele (communities of closure); anti-avalikkusele (anti-public) (Cammaerts 2007: 73); paremäärmuslikku ideoloogiat võimendavale ja taastootvale filtrimullile (O'Callaghan et al. 2013, 2015). Sellise paremradikaalset maailmavaadet kinnistava kajakambrisuhtluse paradoksina toovad mitmed uurijad välja selle rahvusvahelised ning koguni rahvuse-ülesed mõottmed. Erinevad paremäärmuslikud sõlmekesed on üksteise tegevusest ja ideedest online-suhtluse vahendusel teadlikuks saanud ning ühi- 
selt on hakatud koonduma identiteedidiskursuse alla, mille retooriliseks keskmeks on valge $\operatorname{rass}^{2}$ (Daniels 2009, 2012; Caiani \& Kröll 2014; Grumke 2013).

Eelmainitud autorid on viinud läbi nii kvalitatiivseid kui ka kvantitatiivseid uurimusi, mis kaardistavad kõige levinumaid kajakambrites korratavaid ideid, samuti on analüüsitud paremäärmuslike suletud kogukondade koondumist konkreetsete sotsiaalmeedia platvormide (nt YouTube, Twitter, Tumblr, Facebook, mitmesugused foorumid jne) ümber. Samas ei ole senised tööd selgitanud, millised üldisemad tähendusloome eripärad sellist suhtlust iseloomustavad. Seame oma artikli eesmärgiks selle tühimiku täitmise ning püüame selgitada kajakambrisuhtlusele aluseks olevaid mehhanisme kultuurisemiootika raamistike, ennekõike Juri Lotmani autokommunikatsiooni mõiste abil. Keskendume tähendusloomet määravatele ja suunavatele dominantidele, mis garanteerivad struktuuri integreerituse (Jakobson 1971a: 82). Analüüsime diskussiooni, mis kerkis esile seoses massilise põgenike sisserändega Euroopasse. ${ }^{3}$ 2015. aasta kevadel sai alguse põgenike-teemaline aktiivne avalik arutelu, mis intensiivistus Eestis eriti pärast Euroopa Liidu poolt liikmesriikidele kehtestatud sisserändajate vastuvõtmise kvootide avalikustamist. ${ }^{4}$ Näitematerjalina keskendume eesti paremäärmuslikele blogidele ("Rahvuslane", "Koobas", "Rahvuslik blogi" ja "BH RuZZland"), kus rändekriisi temaatikat kõige aktiivsemalt käsitleti. Mainitud blogid toimivad kui paremäärmusliku infovõrgustiku olulised sõlmed: seal jagatakse rohkelt linke mitmesugustele sekundaarsetele allikatele, näiteks (maru)rahvuslikele kodulehekülgedele, Facebooki-gruppidele, ajakirjadele, YouTube'i videotele, foorumitele jne. Me ei väida, et avatud dialoogiline kommunikatsioon toob ilmtingimata kaasa suletud kommunikatsioonile vastupidise ühiskondliku tulemuse ega püüa artiklis mõjutada kedagi pooli valima. Oluline on siin ennekõike tähendusloome eripärade uurimine, mitte aga "õigete/valede" seisukohtade esiletoomine.

Teine eesmärk seondub autokommunikatiivsete protsesside endi mitmekülgsema mõtestamisega. Juri Lotmani (2010a: 73) järgi osutab autokommunikatsioon eripärasele suhtlusprotsessile, kus adressant ja adressaat langevad kokku. Lotman rõhutab, et läheneb autokommunikatiivsete protsessidele võrdlemisi heuristiliselt, mainides mitmes kohas, et tema selgitused autokommunikatsiooni kohta on visandlikud ja autokommunikatsiooni grammatika loomine seisab veel ees (vt Lotman 2010a: 73-74; 2010b: 148). Autokommunikatsiooni ja kommunikatsiooni vastasmõjude põhjaliku kirjeldamise ja tüpoloogiate loomisega pole kultuurisemiootikas veel tegeletud ning enne tuleks uurida nende mehhanismide kõige iseloomulikumaid väljendusi. Käesolev artikkel püüabki heita pisut valgust raskestimõistetavale ja polariseeruvale autokommunikatsioonile kui kultuurilise mina-mina suhtluse ühele äärmuslikule avaldumisele. 
Olgugi et Lotman (2010b: 148) märgib autokommunikatiivsete protsesside ühe võimaliku tasandina kultuuridünaamika pärssimist ja stampide tekke soodustamist, ei ava ta neid aspekte põhjalikumalt. Pigem keskendub Lotmani käsitlus autokommunikatiivsete protsesside funktsioonidele, mis seostuvad avastamise, õppimise ja taipamisega (Lotman 2010b: 128-129, 132; vt ka Torop 2008: 729). Mitmed Lotmani ideid edasi arendanud autorid näevad semiootiliste üksuste autokommunikatsiooni mehhanismina, mis võimaldab kultuurilist innovatsiooni ning subjekti autonoomialoomet valitsevate diskursuste suhtes (vt Ibrus 2010: 90; Ibrus \& Torop 2015: 3; Schönle 2002: 432; Ventsel \& Raudsepp 2015: 660-672). Samuti on üsna palju räägitud autokommunikatsioonist kui identiteeti kujundavast, autosugestiivsest või teraapilisest suhtlusvormist, mille käigus toimub enesekorrastus ning oluliste sihtide ja väärtuste selginemine (Han 2014: 527; Hartley 2014: 4; Kallio \& Sandström 2009: 84-85; Lindström 2010: 363). Need käsitlused näevad autokommunikatsiooni üsna optimistlikus valguses: see on midagi, mis aitab kaasa indiviidi/kultuuri heaolule või arengule. Meile teadaolevalt on seni vaid üksikutes töödes kirjeldatud olukordi, kus autokommunikatiivsed protsessid viivad suletud ning võrdlemisi liiase s.t stereotüüpe taastootva suhtluseni (Lepik 2007: 76-80; Madisson \& Ventsel 2014: 86; Ventsel 2016; Randviir 2018: 241).

\section{Paremäärmuslaste veebisuhtlus kui sulguv autokommunikatsioon}

Kultuuri võib määratleda organiseerituse (informatsiooni) valdkonnana inimühiskonnas, ja see on oma "sisemisest" vaatepunktist alati vastandatud välisele desorganiseeritusele (Ivanov et al. 1998: 68). Suhestumine välisega määrab ära ka kultuurisisese domineeriva tähendusloome spetsiifika. Kultuurilisest kommunikatsioonist moodustab paremäärmuslik online-suhtlus marginaalse osa, mis koondub ennekõike rassilise ja/või rahvusliku unikaalsuse retoorika; rassilise ülimuslikkuse, üleoleku ning erakordsuse idee ümber; veel iseloomustab seda suur rassilise/etnilise "teise" määratluste repertuaar ning utoopilis-revolutsiooniline maailmavaade, mis seab eesmärgiks eksisteeriva korra kukutamise (Back 2002: 632). Lisaks osutatud tunnustele võib paremäärmusliku tähendusloome karakteristikutena märkida ksenofoobiat, valitsevale võimuaparaadile ja pluralismi-ideaalile vastandumist, fundamentaalse inimeste vahelise võrdsuse printsiibi hülgamist (Rydgren 2004: 4).

Juri Lotmani järgi saab kultuurilises kommunikatsioonis tervikuna eristada kahte üldisemat tendentsi: väljapoole suunatud kommunikatsiooni, mille 
eesmärk on oma seisukohtade (teate) edastamine ja võimaliku ühisosa leidmine teiste semiootiliste ühikutega (mina-tema kommunikatsioonitüüp) ning sissepoole suunatud kommunikatsioon, mida siinses artiklis käsitleme autokommunikatiivse süsteemi (mina-mina kommunikatsioonitüüp) kontseptsioonist lähtuvalt (Lotman 2010b). Reaalsetes kommunikatsioonisituatsioonides esinevad need tendentsid põimunult, ent analüütilisel tasandil on võimalik tuvastada emma-kumma tüübi domineerimist (Lotman 2010b: 147). Seejuures võime nii "mina" kui ka "tema" tasandit vaadelda ka abstraktsemate kategooriatena. Lotman rõhutabki, et autokommunikatsioon toimib eelkõige siis, kui käsitleme sõnumi saatja/vastuvõtjana suuremat kogukonda, nt rahvuslikku organismi või inimkonda kui tervikut, üksikisikute puhul on see suhteliselt teisejärguline (Lotman 2010a: 73).

Lotmani järgi jääb autokommunikatiivses mina-mina süsteemis teade samaks ega lisa teate saajale uut infot. Niisuguses kommunikatsiooniprotsessis formuleeritakse teate saajale juba teadaolev info ümber ja see omandab uudse tähenduse tänu uue (teise) koodi lisandumisele. Lähtesõnum kodeeritakse ümber põhimõtteliselt teistsugustesse struktuuriühikutesse ja sellele antakse uue sõnumi jooned. Info formuleerub ümber teistesse kategooriatesse, kusjuures sisse ei tooda mitte uusi teateid, vaid uusi koode; saatja ja vastuvõtja sulavad kokku ühte isikusse. (Lotman 2010b: 140.) Niisuguses autokommunikatsioonis toimub informatsiooni kvalitatiivne transformatsioon, mis viib mina ümberkujunemiseni (Lotman 2010b: 129). Tänu uuele koodile saame varem teadaolevat infot tähendustada teistsugusest perspektiivist. Hoolimata sellest, et sekundaarne kood püüab vabastada algselt tähenduslikud elemendid üldkeelelisest semantilistest sidemetest, üldkeeleline semantika säilib, kuid selle kohale astub sekundaarne semantika, mis moodustub nende nihete arvelt, mis on tekitatud uue koodi kaudu juba teadaolevat teadet ümber mõtestades ja talle uut staatust andes. (Lotman 2010b: 138.) Autokommunikatsioonile suunatud tähendusloomes püüab kultuur (abstraktne mina - autorite lisandus) info hulka endas kasvatada, selle kvaliteeti tõsta ja selle kaudu iseennast muuta (Torop 2008: 729). Seetõttu sisaldab kultuuriline autokommunikatsioon endas nii vahetu elava identiteedi habituaalse tasandi peegeldust kui ka juhiseid selle tähendustamiseks, soodustades niimoodi metakeelte ja -tekstide kujunemist (Torop 2013: 125). Just erinevate kirjelduskeelte väljakujunemise (koodilise vahendatuse) kaudu toimub vahetu identiteedi tõlgendamine ja korrastamine. Niisuguse protsessi käigus püüab kultuur iseenda jaoks mingit akuutset nähtust selgitada ning seda tehes otsib ta iseendale sobivaid kirjelduskeeli, mistõttu on autokommunikatiivsed protsessid ühiskondlikult sensitiivsetel aegadel eriti intensiivsed (vt Lotman 2009: 15; Ojamaa \& Torop 2015: 64). 
Chris Atton (2006: 286) on osutanud, et paremäärmuslikku veebisuhtlust tervikuna ei iseloomusta üldjuhul alternatiivsele meediale ${ }^{5}$ omane "demokratiseeritud kreatiivsus", kuna sealses inforuumis ei ole kohta ideede ja argumentide vahetamiseks ja konsensuslikuks väljaarendamiseks. Paremäärmuslikus (auto) kommunikatsioonis toimub pidev mõtestamisprotsess, kuid teadete semantika on justkui väga piiratud mahus (stampides) ette antud ega võimalda uue info vahetamist. Eesti paremäärmuslikus online-kommunikatsioonis koondub teadete ühtsus Eesti rahvuse eksistentsiaalse ohustatuse, riikliku suveräänsuse ja kultuurilise minapildi kaotamise, võõrmõjude ohtlikkuse jms teemade ümber. Suletud autokommunikatsioonis on infovalik avatud eelkõige seostele, mida potentsiaalne adressaat juba eelnevalt teab (Madisson \& Ventsel 2014). Muusse ei süvenetagi. Teate semantiline nihe saab võimalikuks, kuna lisandub uus kood, mille kaudu juba teadaolevat infot ümber mõtestatakse. Nii võime kohata eelpool osutatud teemade ümbertähendustamisi majandusliku ("migrandid on ohuks meie rahvuse edasikestmisele, kuna võtavad ära töökohad ja on koormaks majandusarengule"), sotsiaalse ("võõraste sotsiaaltoetused tulevad eesti inimeste arvelt"), kultuurilise ("nad kannavad burkasid ja on ohuks eesti kultuurile") jne koodi vahendusel. Autokommunikatiivne seosteraamistik, mis organiseerib paremäärmuslaste kõige erinevamaid tõlgendusi, leiab tänu uue koodi lisandumisele taas tõestust, laiendades ja süvendades veelgi põhjuste ringi, mis rahvuslikku vaimsust ohustavad (Madisson \& Ventsel 2014: 87).

Loomulikult ei ole selline kajakambriline kommunikatsioon omane üksnes paremäärmuslike ideede pooldajatele. Camelia Gradinaru on osutanud, et pidev sotsiaalmeediasuhtlus liiga sarnast profiili omavate partnerite vahel võib viia puuduliku peeglimina konstrueerimiseni. Refleksiooni aluseks võetakse liiga ühetaoliselt mõtlevate inimeste grupp, mille baasilt on väga keeruline aduda eluterves annuses uudseid või opositsioonilisi vaatenurki (Gradinaru 2013: 101). Vastupidiselt ootustele, et internet soodustab arutlevat suhtlust, ei mahene sellistes homogeensetes kogukondades välja kujunenud vaated, kui selle liikmed opositsiooniliste seisukohtadega lähedalt kokku puutuvad (isikliku dialoogi olukorras nt pereliikmete jt lähikontaktide puhul) (Wojcieszak 2010: 645-647). Kui fundamentaalselt erinevat või koguni oponeerivat perspektiivi omav vestluspartner püüab põhjendada vaateid, mis suletud kogukondades kristalliseerunud väärtusi ning identiteedimarkereid kuidagi kahtluse alla seavad, siis on pigem tõenäoline, et olemasolev polarisatsioon süveneb veelgi (Wojcieszak \& Price 2010: 331).

Meie arvates võib hermeetilist tähendusloomet mõtestada autokommunikatsiooni mõiste kaudu. Sellise tähendusloome esimese tunnusena eristame antiteetilise mudeldamise dominanti. 


\section{Antitees kui sulguva autokommunikatsiooni dominant}

Paremäärmuslik online-suhtlus ei võimalda enamasti väärtuste ja normide suhtelisuse tajumist ega tunnusta tõlgendusteede ja vaatepunktide paljusust. Pigem kipub sealne kommunikatsioon jääma suletuks ja paljuski ennustatavaks, kuna infoloome aluseks on antiteetiline mudel, mis jagab maailma binaarse loogika alusel: moraalseks ja ebamoraalseks, kasulikuks ja kahjulikuks, sõpradeks ja vaenlasteks jne. Binaarne mõtlemine ei tunnista kokkupuutepoolte suhtelist võrdsust, mis lubaks eeldada vastaspoole õigust kui mitte just tõele, siis kas või olemasolule (Lotman 2007: 26). Euroopa rändekriisile keskenduvates postitustes tuli selline binaarne loogika küllaltki jõuliselt esile. Kokkuvõtlikult võib märkida, et aatelised, õiglased, printsipiaalsed, ratsionaalsed, tasakaalukad, propagandale mittealluvad rahvuslikud põliseestlased (laiemalt kogu Euroopa (maru)rahvuslased ning valge rassi eest seisjad) vastandatakse valelikele, kasuahnetele, pidetutele, kahepalgelistele, ebaloomulikele, rumalatele, hüsteerilist ja emotsionaalset retoorikat kasutavatele gruppidele (nt Eesti valitsusparteid, Euroopa Liidu struktuuride esindajad, liberaaldemokraatliku maailmavaate, mitmesuguse vähemuste eestkõnelejad) ning ka korruptiivse meedia ja haridussüsteemi tõttu n-ö ajupestud tavakodanike massidele. Eriti kujukalt väljendub antiteetiline vastandumine järgmises tsitaadis, kus erinevate motivatsioonidega teisitimõtlejad lausa vaenlasteks kuulutakse:

pole vahet, kas ajupestud kasulike idiootidena, kas rumalast idealismist, äraostetutena, "progressiivse" ideoloogia levitamise missioonitundest, või selgest kurjast destruktiivsest vihkamisest oma rahva ja maa vastu - sellist hülgemöla pagulastest, sallivusest ja avatusest jms progressiivsetest nähtustest rääkida on kuritegelik ja see kes seda teeb, see on riigi ja rahva VAENLANE, kes valmistab meie jaoks ette põhimõtteliselt sedasama, mis toimus hiljuti Pariisis (http://rahvuslane.blogspot.com.ee/2015/11/ mart-metsalalt-suureparane-raadiosaade.html). ${ }^{6}$

Antiteetiline modelleerimistüüp vajab jätkusuutlikuna püsimiseks kahjuri olemasolu, mistõttu genereeritakse vaenlase ohtlikkusega seonduvaid representatsioone pidevalt juurde (Lotman 2007: 40). Üsna levinud on postitused, mis räägivad konservatiivse maailmavaate esindajate vägivaldsest suukorvistamisest $^{7}$ või koguni hukkamisest ${ }^{8}$ ja eksistentsiaalsest ohust rahvusriikidele ${ }^{9}$, väga sage on ka osutamine eestlaste või valge rassi vastasele genotsiidile. ${ }^{10}$ Märgitud ohtude kujutamist näitlikustab järgmine mõttekäik:

Reaalsuses toimib see [kultuurkommunistide ja vasakliberaalide nägemus sallivusest ja kultuuri rikastamisest - autorite lisandus samast postitusest] kui kohaliku populatsiooni järk-järguline välja tõrjumine ning selle 
kritiseerijate natsideks tembeldamine. See on süstemaatiline hävitustöö, mitte sallivus, kus mistahes iganenud ettekäände alusel lõdvendatakse kodakondsuspoliitikat ja elamislubade reegleid. Sallivus on koodsõna valgele genotsiidile (http://koobas.net/2015/04/03/teretulemast-rootsi/ ei ole enam kättesaadav, dubleeritud http://rahvuslane.blogspot.com. ee/2015/04/koobas-teretulemast-rootsi.html).

Antiteetilise vaenlase puhul on tähelepanuväärne, et see konstrueeritakse sageli oma struktuuride miinusmärgilise sümmeetrilise koopia ehk peegelprojektsioonina (Lotman \& Uspenski 2013: 223). Peegelprojektsioonile eelneb tihti projektsioon ehk esmalt omistatakse "meie" probleemid "nendele" ja seejärel luuakse peegelprojektiivne antitees: "nende" probleemidele vastandatakse markeeritud nulltunnus ehk probleemide puudumine "meie" struktuuris (Lepik 2007: 72). Niisugune suundumus on tugevalt esil ka meie vaadeldud postitustes, üsna levinud võte on ideoloogiliste vastaste süüdistamine sallimatuses, äärmusluses, vähemuste tagakiusamises, rassismis ja natsismis ${ }^{11}$. Näiteks kirjutatakse:

Heil Sutroppid! Heil! Heil Antifašistid! Heil meie natsikütid! Heil - küll oleme tublid õigusriigi kaitsjad! Heil meile! Heil - me mõistame hukka natsismi! Aga tahate näha vihast vahutavaid ekstremiste? Siis vaadake peeglisse! Muidugi on teil võim ja jõud peegel puruks peksta, sest sealt vaatav ilge tärkav natsilõust teile ei meeldi. Jah, teil on see jõud ja võim. Aga mida see muudab? Teie poolt loodav uus ühiskond on hirmü̈hiskond, kus teisitimõtlejaid võib karistamatult sildistada ja peksta, lõpuks ka tappa. Kas te seda soovitegi oma hüsteeriaga saavutada? (http://rahvuslik. blogspot.com/2015/03/je-suis-ekre-sona-ja-mottevabaduse-ning.html ei ole enam kättesaadav, dubleeritud http://rahvuslane.blogspot.com. ee/2015/04/je-suis-ekre-sona-ja-mottevabaduse-ning.html)

Selline retoorika võimaldab positsioneerida end moraalse ohvrina, keda valitsevad jõud vaenavad (Madisson \& Ventsel 2015: 74-75; Madisson 2016), samuti lubab see pahatahtliku ning destruktiivsena tajutud vastase süüdistusi juba eos pareerida ning omistada vaenlastele täpselt samasugused taunitavad omadused, millega viimased iseloomustavad paremäärmuslasi.

Juri Lotman ja Boriss Uspenski (2013: 226) toonitavad, et semiootilisi üksusi, kus antiteetiline modelleerimine tugevalt domineerib, võib iseloomustada eraldumispüüe ja soov end välismõjude eest kaitsta. Piirjuhul võidakse koguni iga põhimõtteliselt teistlaadi väljendust ja seoseid kandvat üksust tajuda kui ohtlikku kahjuristruktuuri (Lotman \& Uspenski 2013: 224). Sellise vaenlase õõnestava, halvava või koguni hävitava mõju eest üritatakse end kaitsta kõikvõimalike kontaktide sulgumise teel. Eelkirjeldatud sulgumis-püüdluse võtab kokku ühes vaadeldud blogis kajatatud mõte: 
Kui piiride kindlustamine ja immigrantide riigist eemal hoidmine on turvalisuse ja jõukuse pant, siis tuleb seda teha, ohverdades mõneks ajaks mugavuse passita reisida. Parem suletud kui surnud, on minu seisukoht (http://rahvuslane.blogspot.com.ee/2015/11/martin-helme-parem-suletudkui-surnud.html).

Seoses pagulaskriisiga kerkib paremäärmuslikus online-suhtluses selgelt esile islamofoobia ${ }^{12}$. Islamis (mida mõistetakse sageli islamismi sünonüümina) nähakse barbaarset ja vägivaldset uskumustesüsteemi, mis õigustab mitteuskujate tapmist ning vägistamist. ${ }^{13}$ Samuti kardetakse, et islamipropaganda ja värbamismehhanismid on nii võimsad, et peagi võib suurem osa läänemaailmast islamiseeruda ning seada ohtu Euroopa rahvusriigid ja nende traditsioonid. Näiteks kirjutatakse:

Pole midagi jäledamat, kui oma maa patrioodid peavad marssima politsei kaitse all ja immigrantide, moslemite ja vasakrämpsu räuskamise saatel. See rämps tõstab ka Eestis üha julgemalt pead ja mõnitab avalikult rahvuslasi ja nende ettevõtmisi. ISLAM ON KATK, MIS HÄVITAB KÕIK, MIS MEILE KALLIS JA OMANE ON (http://rahvuslik.blogspot.com. ee/2015/11/inglismaal-arreteeriti-mees-kes.html - ei ole enam kättesaadav, dubleeritud http://rahvuslane.blogspot.com.ee/2015/11/inglismaalarreteeriti-mees-kes.html).

Peet Lepiku (2007: 77, 80) sõnul toimib antitees kui kultuurilise autokommunikatsioni vallandaja. Paremäärmuslikus veebisuhtluses funktsioneerib see kui kultuurimälust pärinev lisakood, mis korrastab ümber teate primaarse semantika. Teate tavatähendus muutub antiteesi mõjualas üsna ebaoluliseks. Antiteesi valguses kerkib esile selle teate n-ö laiem tähenduslikkus: oluline pole mitte üksiknäide, mille poolest vaenlane ohtlik on, vaid asjaolu, et ta kinnitab kultuurilist stereotüüpi (Lepik 2007: 80; Madisson \& Ventsel 2015) "nende" ebamoraalsusest ja järelikult "meie" moraalsusest. Tähenduslik ei ole mitte konkreetne normist kõrvalekaldumise juhtum ("islamipropaganda", "immigrantide, moslemite ja vasakrämpsu räuskamine"), vaid asjaolu, et see seob olemasolevaid kultuurilisi stampe üha uute kontekstide ja assotsiatsioonidega. Lausete "Suurem osa Läänemaailmast võib islamiseeruda", "Islam on katk mis hävitab kõik..." puhul osutavad sõnad "suurem osa" ja "kõik" võimalusele näha tulevikus Eesti (ja Euroopa) rahvusi tabavate eksistentsiaalselt ohtlikke sündmuste/protsesside taga üht põhjust - islamit. 


\section{“Õigetele" tekstidele orienteeritus kui sulguva autokommunikatsiooni dominant}

Paremäärmuslaste online-suhtluses, mida iseloomustab suuresti antiteesil rajanev tähendusloome, võib täheldada teisigi dominante, mis lasevad niisugust protsessi mõtestada sulguva autokommunikatsioonina. Paremäärmusliku kajakambrisuhtluse üks tunnuseid on hermeetiline seosteloome jõuline esiletulek. Umberto Eco on märkinud, et hermeetilist kommunikatsiooni juhib väga võimas analoogiamehhanism, mis kord juba käivitununa on peaaegu peatumatu. Iga kord kui avastatakse analoogia, osutab see omakorda uuele analoogiale jne. Niisugustes tõlgendustes kinnitatakse sarnasuse-kriteerium äärmise vähenõudlikkuse ja paindlikkusega, mille tõttu tajutakse, et see, mis usutakse olevat märgi tähendus, on tegelikult märk märgi kaugemast tähendusest. Seega on hermeetilise semioosi puhul väga tavaline, et tõlgendaja hakkab mis tahes nähtuste tagant otsima varjatud motiive. (Eco 1990: 163-166.) Niisugusel analoogiamehhanismil tugineval modelleerimistüübil on paremäärmuslikus kajakambrisuhtluses oluline kaal. Seoses Euroopat tabanud migratsioonilaine üle arutlemisega paremäärmuslikus kohalikus inforuumis võime täheldada analoogiate loomist erinevate sündmuste ja nende põhjuste vahel: "Tegelikult nii suuremõõtkavalisi ettevõtmisi, nagu Pariisi tulistamised, kaksiktornide õhkimine New Yorgis või Londoni pommiplahvatused, pole võimalik läbi viia ega ette valmistada ilma võimude ja salateenistuste teadmata, vaikiva nõusolekuta ja/või koguni kaasabita. Kõik on ühe ja sama plaani eri osad (autorite rõhutus)."14. Niisugune plaan väljendub peamiselt ühes peamises eesmärgis: "See mis hakkab toimuma Euroopas on täielik hullumaja. Tegelikult on see üks osa valge rassi ja rahvusriikide hävitamisest [...]"15, “[...] kus pagulased, peamiselt islamiusulised ujutavad E[uroopa] Liidu üle"16. Analoogiaprintsiip näeb käesoleva kava elluviijatena Eestis "võimulolevaid äärmusliberaal[e] ja äärmusvasakpoolse[i]d: Reformierakond, Sotsiaaldemokraadid ja ka IRL"17. Aga samuti teisi, esmapilgul kokkusobimatuid toimijaid nagu "ökofašistide ${ }^{18 ", ~}$

seksuaalmarksim[i] või kultuurimarksism[i], mis ei rünnanud enam kapitali, vaid pöördus pehmete väärtuste manu. Marcuse sõnul pidid geidest, lesbidest ja radikaalfeministidest saama uue sotsiaalse revolutsiooni avangard. Need olid kapitalistide poolt põlatud kihid, kellele teatud hetkel lisandus veel Euroopasse valgunud immigrantide mass ja muud vähemused. Pahadeks kuulutati aga valged traditsioonilised heteroseksuaalid.[...]. (http://rahvuslane.blogspot.com.ee/2015/05/ kaasaegse-sotsiaaldemokraatia-hada-ja.html). 
Eesti kultuuriruumis on tähtsal kohal viited lähiajaloo Nõukogude perioodile ("KGB agendid"19; "On taas välja ilmunud uustšekistid, uusjuunikommunistid ja uusküüditajad"20; "äärmuslikud rahvavaenlased, sarimõrvarid"21; "kultuurkommunistid"22 jne). Lotmani järgi lubab niisugune homomorfismil põhinev struktuurisuhe reaalse maailma erinevates nähtustes tunda ära ühe ja sama nähtuse märke, ühe klassi erinevate objektide asemel aga ühtset objekti (Lotman 2002a: 2647-2648). Käesoleval juhtumil kehtestavad analoogiasuhte erinevad toimijad ja nende minevikus põhjustatud või tulevikus põhjustatavad ebameeldivad tagajärjed.

Nimetatud tähendusloome üks olulisi karakteristikuid on tendents samastuda enesekirjelduse tasandil õige teksti või tekstikogumiga (Lotman \& Uspenski 2013: 219). Tekstidele orienteeritud tähendusloomes vaadeldakse ennast kindla pretsedentide, kasutusjuhtude ja tekstide summana ning õigeks peetakse seda, mis eksisteerib (tekstis - autorite lisandus) (Lotman 2010a: 61). Eesti paremäärmuslikus veebisuhtluses, mis koondub migratsioonikriisiga kaasnevate ohtude ja nende lahendamise võimaluste temaatika ümber, kerkivad esile kahte tüüpi tähendusloomet kujundavad tekstid. Esimese tüübi moodustavad tekstid, mis eksisteerivad terviklikul kujul ja mille autorlust ei ole raske tuvastada. Peamiseks tekstiks, millele oma argumentatsioonis toetutakse, on Eesti Vabariigi põhiseadus. Näiteks märgitakse: "Meie rahvuslus on väikerahva rahvuslus, mis ei ole suunatud mitte teiste vastu (nagu on suurrahva šovinismis), vaid kestmajäämisele, milleks kohustab meid meie Põhiseadus"23. Paremäärmuslased käsitlevad seda peamise käitumist ettekirjutava tekstina, kuna “[p]õhiseaduse järgi on Eesti endiselt iseseisev riik ja iseseisev riik ei täida võõrriikide ega eraettevõtete ettekirjutusi. Mingeid pagulaskvoote meie põhiseaduses ei ole ja seega pole millestki rääkida [...] Kes ei ole kunagi toetanud eesti kultuuri, ärgu rääkigu kultuurist ega multikultuurist"24. "Riigitähtsusega probleemid on põhiseaduse järgi esiteks rahva väljasuremine ja massiline ellujäämispagulusse siirdumine ning teiseks kultuuriline allkäik."25 Blogipostituste vahendatud parempoolse maailmavaate äärmuslikkus on varieeruv ja sugugi kõik postitused ei sisalda endas selgelt rassistlikke ja ksenofoobseid osutusi. Samas on tähendusloome üldine tonaalsus äratuntavalt paremradikaalne, millest annab märku ka tendents omistada sõnadele väärtus-essentsialistlik mõõde, jättes samas lahti seletamata, mida selle all silmas peetakse. Nii räägitakse eestluse kultuurilisest sisust ennekõike nahavärvi ja rassilise kuuluvuse kaudu "Ka Eesti Põhiseadus näeb Eesti riigi peaülesandena Eesti riigi, rahva, kultuuri ja keele säilitamise läbi aegade. Kes ütleb, et rahval ei ole nahavärvi, on paraku puudulike teadmistega. Ükskõik milline teatmeteos ütleb selgelt, et eestlased kuuluvad valgesse, europiidsesse rassi.[...] Mustanahaline eestlane on sama 
võimatu, kui habemega naine". ${ }^{26}$ Postitustes peaaegu puuduvad kultuurilise enesekirjelduse katsed, see aimub üksnes ägedas vastandumises sellele, mis on kuulutatud võõraks. Nahavärvi kaudu kultuurilise identiteedi määramine ei selgita, kuidas eesti kultuur erineb teistest "valgetest" kultuuridest.

Sama tekstitüübi puhul saame eristada ka tekste, mis kindlate autoritekstidena (nt "1984", " $451^{\circ}$ Fahrenheiti", ${ }^{27}$ " Gulagi arhipelaag" ${ }^{28}$ jne) funktsioneerivad hoiatavate näidetena peatsest allakäigust, milleni viib poliitiline korrektsus ja migratsiooniprobleemist rääkimise võimatus. "Lähed mööda tänavat, paugud käivad ja inimesed kukuvad. Täna vaid jumalat, et ise veel elad! Kas tuleb tuttav ette? Sellise maailma pani oma raamatusse "1984" kirja isehakanud maailmavalitsejate salaplaane tundev George Orwell”. ${ }^{29}$

Teine levinud tekstide tüüp seondub aga peamiselt kultuurimälus kollektiivselt kujunenud tekstide kihistusega. Siia tekstitüübi alla kuulub üldisem ohvritekst, mis seondub Eesti kontekstis ennekõike 700aastase orjapõlve, küüditamiste ja nõukogude okupatsiooniga, mille jätkumise märke nähakse päevapoliitilistes sündmustes. Oluliste sündmuste/suundumuste kaardistamiseks või tulevikuvisioonide artikuleerimiseks pöördutakse siin ennekõike omaenda mälukihistuste poole, mistõttu kipuvad olemasolevad seosed aja jooksul võimenduma ning identiteediloome aluseks olevad vastandused üha enam polariseeruma. Nii seotakse paremäärmuslikus suhtluses ühtseks mentaalseks tervikuks Euroopa Liit ja Nõukogude Liit. Võime lugeda:

Esimesena võeti oma [Euroopa Liidu - autorite lisandus] PR-arsenali NSV Liidu kui kõikvõimsa impeeriumi idee, vennaliku Euroopa rahvaste pere mudel, kus võrdne tähtsus nii sakslastel, kreeklastel ja poolakatel. Euroopa Liit pidi saama uue õnneliku superimpeeriumi sünonüümiks. (http://rahvuslane.blogspot.com.ee/2015/05/kaasaegsesotsiaaldemokraatia-hada-ja.html)

Sama olulised on analoogiad väliste võimurite ja kohalike võimupoliitikute ning kallutatud meedia- ja haridussüsteemi vahel, mida tajutakse sageli ülemaailmse NWO ehk uue maailmakorra erineva astme agentidena, (vt Madisson \& Ventsel 2015; Madisson 2016). Niisuguse tegevuse tagajärgi kujutatakse eksistentsiaalse ohuna eesti kultuurile, aga selle kaudu eesti rahvusele tervikuna. Nii võime lugeda, et "eestlaste küüditamine vaesushoova abil on hästi õnnestunud, sellega on massiimmigratsiooniks loodud eeldused, sotsiaalsest põletatud maa, lebensraum illegaalsete immigrantide ja kolonistide uuele lainele" ${ }^{30}$ ja "Eesti rahva väljaküüditamisel Moskva käsulaudade alusel ja teiste rahvaste sisseküüditamisel Eestisse Brüsseli kvootide tingimustel on mõlemal kahjuks karmilt ühine lõpptulemus - üks rahvas jääb oma põlisel kodumaal jätkusuutmatult vähemusse". ${ }^{31}$ 
Teise tüübi alla käib ka stereotüüpne mälutekst mustanahalisest mehest, kes on kriminogeensem, andub seksuaalsetele elumõnudele ja on seega suurema tõenäosusega vägistaja. Postitusi läbivad erinevad uudised Põhjamaades toimunud massilistest vägistamisjuhtudest,${ }^{32}$ kohalike inimese kartustest oma kodukandis vabalt liikuda, politsei jõuetusest immigrantide asurkonnas patrullida jne. Seejuures on oluline, et analoogia mehhanism laseb erinevatel õigetel ja valedel väljendustel/tekstidel näida üksteise suhtes analoogsena ning nii luuakse analoogiasuhe ka islamiusulistega, kes õhutavad "inimesi "pühale" vägivallale - mõrvadele, tapmistele, vägistamistele". ${ }^{33}$

Tekstide kogumina määratletavat semiootilist üksust organiseerib ettekujutus, et kõigel, mis oma seisukohtadele vastandatakse, peab ühtlasi olema oma spetsiifiline väljendus - kuid väär (vale) väljendus (Lotman \& Uspenski 2013: 223). Kujukalt ilmneb niisugune tendents nimetamise protsessi juures, mille üks olulisi ilminguid on partnerile nime andmine. See on samaväärne tema võtmisega minu tähendusmaailma, tema kodeerimisega minu koodiga ja talle koha määramisega minu maailmapildis (Lotman 1999b: 68). Nimetamise juures on antiteetilise dominandiga kommunikatsiooni puhul oluline samasuse tunnetamine nime ja objekti vahel, s.t objektide nimi peab seal peegeldama nende olemust (vt ka Madisson \& Ventsel 2012). Euroopat tabanud põgenikekriisiga seoses on nime andmine äärmiselt oluline, sest sellega suunatakse teksti vastuvõtjat kindlasse tõlgendusraamistikku. Korduvalt võime lugeda postitustest üleskutseid nimetada asju õigete nimedega. "Viimasel ajal on meedias palju räägitud nn "põgenikest” ja "pagulastest," eriti seoses Vahemerel toimuva kriisiga [...]"34. "Fakt on see, et enamus neist sisserändajatest pole sugugi põgenikud, vaid sotsiaalabimigrandid (autorite kursiiv), kelle peasihtkohtadeks on riigid, kus kõige kergem taotleda sotsiaalabi peal elamist". ${ }^{35}$ Poliitilist korrektsust järgides võib niisugune nimetamisviga postitajate silmis kaasa tuua kaugeleulatuvad tagajärjed, "kuna enamus "pagulasi" on illegaalsed paberiteta isikud, valdavalt noored tugevad mehed, paadiga üleveo tasud aga kopsakad, on alust arvata, et tegelikult on tegu kas majanduspõgenike või islamiriigi varjatud "saadikutega"."36 Levinud võtteks on jutumärkide kasutamine, mille eesmärgiks on näidata vastaspoole (enamasti peavoolumeedias leviva) nimetamise valelikkust. Nime andmine on ka mehhanism, mille abil luuakse analoogia erinevate sündmuste ja toimijate vahel (vt eelpool "okupant", "migrant", "kolonist", mis Eesti kultuuris kannavad osutusi nõukogude ajastule).

Rääkides online-kommunikatsioonist on Ameerika folklorist Robert Glenn Howard käibesse toonud vernakulaarse autoriteedi mõiste, mis kujuneb tänapäeval peamiselt vernakulaarse veebi keskkonnas. See tugineb kujunenud kohalikule traditsioonile ja on mitte-institutsionaliseeritud (st ei tugine formaalsetele hierarhiatele). Erinevalt institutsionaalsest autoriteedist 
ilmneb vernakulaarne (kohaliku päritoluga) autoriteetsus ennekõike siis, kui indiviid usaldab väidet, kuna seda ei ole esile toonud institutsionaalne autoriteet, olgu viimaseks siis niisugused formaalsed institutsioonid nagu kirik, meediakorporatsioon või muu selline. Lühidalt öeldes saamegi vernakulaarset dialektiliselt defineerida institutsionaalsest eristuvana (Howard 2011: 7-10). Eestis moodustab paremäärmuslik online-kommunikatsioon ühe osa kohalikust veebisuhtlusest. Võib öelda, et vastandumine institutsionaalsele sfäärile ja peavoolu seisukohtadele, õige ja vale selge kaardistamine on siin oluline suhtlust konstitueeriv kese.

Üha enam saab ilmsiks tõsiasi, et peavooluajakirjandus on Eestis muutunud täpselt sama räigeks ajupesu teostajaks, nagu oli nõukogude ajakirjandus eesotsas Pravdaga. Oli vaid üks tõde ja kes selle vastu oli, tembeldati kontrevolutsionääriks, kodanlaseks, tagurlaseks jms uuele võimule kõlbmatuks rämpsuks (http://rahvuslane.blogspot.com.ee/2015/09/ peavooluajakirjandus-eriti-delfi-ohutab.html).

Seetõttu hinnatakse veebisuhtlust paremäärmuslikes võrgustikes selgelt autoriteetsemana kui peavoolumeediat. Viimast seostatakse analüüsitud blogides võimustruktuuridega, kus levitatakse valet või rahvuslikule eksistentsile koguni ohtlikku infot (homopropaganda, multikultuursed ideed jne). Vernakulaarne autoriteet tugineb siin kultuurimälus ringlevatele tekstidele (nt ohvritekst, põhjamaise valge rassi idee, narratiiv viikingite järeltulijateks olemisest jne), mida oma perspektiivist tõlgendatakse. Samuti rajaneb see autoritel, kelle seisukohad olulisel määral dominantsetele vastanduvad.

Kokkuvõtvalt võime öelda, et niisugune tekstidele orienteeritud kommunikatsioon on selgelt autokommunikatiivse iseloomuga, kuna kapseldub juba olemasolevasse tähendusmaailma, otsides enesekinnitust õigetest tekstidest, traditsioonist ja peavoolu seisukohtadele vastandumisest. Siin võib põhimõtteliselt puududa soov endast väljapoolsega suhestuda ja dialoogi astuda. Seejuures, nagu osutab Peet Lepik, soodustavad autokommunikatiivsed protsessid tekstide muutumist metatekstideks (Lepik 2007: 78). Kuna autokommunikatsioon sisaldab endas nii objekttasandi peegeldust, kui ka juhiseid selle tähendustamiseks (Lepiku 2007: 80), siis metatekstid tõusevadki kõrgemale tasandile kui objekttasandi tekstid, funktsioneerides niimoodi kui näited reegli kohta. Ülal osutasime, et paremäärmuslaste veebisuhtluses tõlgendatakse käesolevat hetke ja võimalikke musti tulevikustsenaariume (hukutav poliitkorrektsus, sõnavabaduse täielik kadumine, eestlaste kultuuriline ja füüsiline väljasuremine) kultuurimälus olevate tekstide valguses ("1984", ohvritekst). Viimased funktsioneerivad hoiatavate näidetena tulevikust, mida saab vältida üksnes 
siis, kui käitutakse varasemast erineval viisil (võimulolijate reeturliku palge paljastamine, islamipõgenike sissevoolu takistamine jne). Kuigi Lotman toob välja, et tekstidele orienteeritusega ei kaasne enesekirjeldamise püüd (Lotman 2010a: 62), siis just tekstide metatekstideks muutumine toob kaasa viimaste käitumist ettekirjutava funktsiooni, sest selle funktsiooniga seostub identifikatsioonimehhanism, erinevuste elimineerimine ning teksti lähendamine standardile ja normile. ${ }^{37}$ Niisugused tekstid õpetavad kindlat käitumist ja näitavad ette õiged väärtushinnangud (Lotman 2010a: 61).

\section{Suletud autokommunikatsiooni faatiline dominant}

Nagu eelpool osutatud, toimivad paremäärmuslikud vernakulaarsed veebid sageli kui autokommunikatiivsed kajakambrid, kus sõnumi saaja teab põhimõtteliselt juba ette, millist tähendust teade kannab. Sellist kommunikatsiooni kujundavad paljuski rahvusradikaalse maailmavaate ümber koondujate ühismälul põhinevad tähendusšabloonid ehk stereotüübid. Isegi kui sealsed sõnumid sisaldavad uusi infokilde (nt uusi faktoreid, päevakajalisi sündmusi, senitundmatuid agente), saavad need tähenduslikuks eelkõige olemasolevatesse ühistesse tõlgendusraamistikesse sobitumise kaudu. Seetõttu võib öelda, et niisuguse kommunikatsiooni semantiline väärtus on sageli pigem madal. Teisalt aga kompenseerib seda tugev kogukondliku sideme loomise potentsiaal. Järjepidev kajakambrisuhtlus kasvatab ja ühtlustab kogukondlikku mälu (sh ühist osutuste repertuaari) ja tugevdab olemasolevate vaadete legitimeerimist võimaldavaid retoorilisi raamistikke. Lisaks tagab see ka suure tõenäosusega motivatsiooni ja kindlustunde edasiseks suhtluseks, kuna "õigel" viisil konstrueeritud teated tagavad positiivse tagasisideahela (Jamieson \& Cappella 2008: 77,240 ). Sellises kajakambrisuhtluses saame eristada järgmist dominanti, mis tugineb Jakobsoni keelefunktsioonide eristusele, nimelt faatilise kommunikatsiooni prevaleerimist.

Jakobsoni järgi on kontaktile orienteeritud faatiline funktsioon seotud eelkõige kommunikatsiooni kehtestamise, pikendamise või katkestamisega. Kõige klassikalisemaks faatilise kommunikatsiooni näiteks toob ta olukorra, kus kontrollitakse, kas telefoniliin töötab. Samas ei piirdu Jakobson kontakti määratlemisel üksnes füüsilise kommunikatsioonikanaliga, vaid rõhutab ka psühholoogiline sideme tekitamist ja alahoidmist saatja ja saaja vahel. Psühholoogilise kontakti säilitamise ja kehtestamise näidetena võib tuua katsed köita kaasvestleja tähelepanu või kontrollida selle olemasolu. (Jakobson 1976: 113.) Meie vaadeldud paremäärmuslikus kommunikatsioonis on sellistel faatilise orientatsiooniga sõnumitel märkimisväärne osakaal. 
Paremäärmusliku suhtluse üks oluline eesmärk on väljendada kursisolekut mõttekaaslaste tegevusega ning markeerida selle suhtes oma tunnustust või hukkamõistu. Zeynep Tufekci toob välja, et erinevalt näost näkku suhtlusest võimaldab online-kommunikatsioon kujukat sotsiaalsete sidemete kuvamist ja demonstreerimist teistele võrgustiku liikmetele, kusjuures on tähelepanuväärne, et sellist suhtlust saab kogeda ja vaadelda ajalis-ruumiliselt distantsilt. Nii põimivad sotsiaalmeedia kasutajad oma sõnumitesse rohkelt faatilist infot: näiteks on võimalik tuvastada vastastikuseid sõbrastaatuse omajaid, aktiivsemat kontakti alalhoidvaid pool-avalike sõnumite vahetajaid, üksteise jagatud info n-ö laikijaid ning ka autoriteetse arvamuse kandjaid, kelle postitusi tihti jagatakse ja kommenteeritakse jne. Sellises faatilises kommunikatsioonis joonistuvad välja selged suhtlemishierarhiad, mis markeerivad teatud kontaktide domineerimist teiste üle, mistõttu on faatilise suhtluse jälgimine sotsiaalse kapitali seisukohalt väga oluline, kuna see peegeldab olulist infot inimese grupikuuluvuse ja staatuse kohta. (Tufekci 2008: 547-548.) Ka eesti paremäärmuslikus võrgustikus võib täheldada tervet hulka sõnumeid, mis koosnevad suures osas teiste rahvusradikaalset või immigratsioonivastast sisu jagavate lehekülgede viidetest, levinud on näiteks osutamine Facebooki gruppidele "EI PAGULASMASSIDELE", "Ei pagulastele", "Estonian Anonymous" (ka selle Youtube'i kanalile). Populaarne on viitamine infoportaalidele "Uued uudised”, "Objektiiv" (ka selle Youtube’i kanalile) ning Rahvuslaste Tallinna Klubi ja Nõmme Raadio kodulehekülgedele.

Sageli kipuvad jagatud viited kattuma (st kujunevad välja autoriteetsed autorid ja tsitaadid) ning tihti esineb ristviitamist ka uuritud paremäärmuslike blogide vahel (Madisson \& Ventsel 2015). Vahel moodustuvad postitused ka mõnest konkreetse inglis- ${ }^{38}$, soome- ${ }^{39}$ või rootsikeelse ${ }^{40}$ teksti kokkuvõttest või mingi tsitaadi tõlkest eesti keelde. Euroopa rändekriisi kontekstis tõuseb meie vaadeldud allikates selgelt esile kursisoleku ja heakskiidu väljendamine erinevates Euroopa riikides edu saavutanud parempopulistlikele või -ekstremistlikele erakondadele, näiteks viidatakse kodulehekülgede, YouTube’i kanalite ja ajaleheartiklite jms kaudu Rahvusrindele (eelkõige Marine Le Peni tegevusele), Põlissoomlastele, Suurbritannia Iseseisvusparteile, Rootsi Demokraatidele ja sellistele rahvusvahelistele liikumistele nagu Pegida, Euroopa rahvusrinne, Smash Cultural Marxism. Samuti demonstreeritakse kursisolekut kohalike rahvusradikaalsete või immigratsioonivastaste erakondade ning organisatsioonide tegevusega, sageli jagatakse infot Eesti Konservatiivse Rahvaerakonna koduleheküljelt, küllaltki levinud on viitamine Eesti Iseseisvuspartei, Rahva Ühtsuse Erakonna ning SA Perekonna ja Traditsiooni Kaitseks tegevusele. On tähelepanuväärne, et aeg-ajalt osutatakse allikatele, mis markeerivad otsest 
seost kristlike institutsiooniga, nt võetakse sageli postituste aluseks artiklid veebiajakirjast Meie Kirik või kirikutegelaste mujal avaldatud artiklid ja Facebooki-postitused, oluliseks infokanaliks on ka Kuressaare Pereraadio.

Jakobsoni ideid edasi arendanud keeleteadlane John Laver (1975: 336) rõhutab, et faatilises kommunikatsioonis vahetatav informatsioon on pigem indeksilist kui referentsiaalset laadi, seal peegeldub kommunikatsioonipartneri aktsepteerimine/mitteaktsepteerimine. Usaldusliku kontakti loomise üheks oluliseks võtteks on ühismälu seoste aktiveerimine. Niisuguse intiimse suhtlusatmosfääri kehtestamisel on tähtis roll lokaalsel semantikal, mis kaldub "koduse", intiimse leksika vormimise poole, kusjuures teksti väärtuslikkust võib tõsta just tema arusaamatuse aste teiste (ehk kolmandate osapoolte) silmis (Lotman 2002b: 171). Vaatlusest tuli sellise leksika ühe näitena välja väljend pederallala, mis on levinud paremäärmuslikes blogides, kuid seda võib kohata ka nt Facebooki-postitustes ja ajalehekommentaarides. Üks autor pakub koguni välja selle väljendi määratluse: "pedelik mõtteviis, et naudi elu ilma igasuguse vastutustundeta (neil ju lapsi pole)". ${ }^{41}$ Teine taoline paremäärmuslikust suhtlusest võrsunud fraas on lilla-roosa $u d u,{ }^{42}$ mida kasutatakse peavoolukultuuris domineeriva liberaal-või sotsiaaldemokraatliku retoorika tähenduses.

On tähelepanuväärne, et ühe ja sama sisu kordamine eri märgisüsteemides muudab selle hõlpsamini meeldejäetavaks ning kasvatab olulisel määral selle tähtsust $^{43}$ (Ojamaa \& Torop 2015: 63), kuna sama teksti või tekstielemendi kordumine ei aktualiseeri vastuvõtja mälus mitte üksnes teksti erinevate variatsioonide koherentsust, vaid ka meediumi-spetsiifilisi võtteid eelmistest kordustest (Ojamaa \& Torop 2015: 73) ${ }^{44}$. Euroopa pagulaskriisiga seonduvates postitustes kujuneb üheks enim korratud tekstiks kindlasti valgete vastane genotsiid, mida esineb nii arvandmeid rõhutavates diagrammides, ${ }^{45}$ YouTube'is jagatud filmides, ${ }^{46}$ arvamuslugudes ${ }^{47}$ karikatuursetes joonistustes või fotokollaažides, ${ }^{48}$ samuti otsest vägivalda kujutavas hirmuäratavas pildimaterjalis ${ }^{49}$ jne.

Mitmed paremäärmuslikule online-suhtlusele keskenduvad uurimused on välja toonud, et ebasoovitavast auditooriumist hoidumiseks ja rühmatunde tugevdamiseks on tähtsal kohal mitmesuguste salakoodide, nt numbrikombinatsioonide, akronüümide (nt $88^{50}, R A H O W A^{51}$ või $P W A^{52}$ ) või konkreetsetest tekstidest (nt siseringile tuntud laulusõnadest, aforismidest, offline-kontekstis vahetatud mõtetest) pärinevate fragmentide kasutamine (Hale 2012: 349; Siibak 2012; Simi \& Futrell 2006: 133-134; Madisson \& Ventsel 2015: 12). Eco (1995: 74) on märkinud, et eriti iseloomulik on kärbitud sõnavara ja neologismide kasutamine. Selline ühismälule osutav faatiline info on oluline, sest see indikeerib vestleja potentsiaalset omaksvõttu kommunikatsioonipartnerina (Radovanovic \& Ragnedda 2012: 12). 
Sõnade redutseerumine, tendents muutuda sõnadest märkideks, märkide indeksiteks, mida saab mõista üksnes vastuvõtja, kes teksti juba ette teab, on Lotmani järgi (2010b: 134-138) autokommunikatiivse süsteemi eriliseks tunnuseks. Niisugust suundumust võis märgata ka eespool kirjeldatud paremäärmuslaste pealtnäha liiasena näivas faatilises kommunikatsioonis, kus leiab aset sama sisu pidev kordamine ja kontsentreerumine ning suhtlemine n-ö suhtlemise enda pärast. Sellega luuakse ja hoitakse aktiivsena sotsiaalseid sidemeid.

\section{Kokkuvõte}

Käesolev artikkel käsitles võrgusuhtluses esile kerkinud polariseeruvate kajakambrite tähendusloomelisi eripärasid. Meie hinnangul aitasid (kultuuri)semiootika raamistikud selgitada hermeetilise kommunikatsiooni keskseid karakteristikuid ning avada selle laiemat kultuurilist funktsiooni. Lisaks sellele demonstreeris meie uurimus, et autokommunikatsiooni kontseptuaalne raamistik on viljakas ka umbse ja stampe taastootva tähendusloome kontekstis.

Keskendusime empiirilises osas eesti paremäärmuslaste n-ö rohujuuretasandi võrgusuhtlusele, täpsemalt võtsime luubi alla postitused, mis keskendusid 2015. aasta kevadel eskaleerunud rändekriisile. Meie analüüs näitas, et paremäärmuslikku online-kommunikatsiooni iseloomustab dialoogile vastanduv enesessesulguv autokommunikatiivne tähendusloome. Sellist hermeetilist suhtlust juhib antiteetiline vastandumine, mis konstrueerib ranged oma ja võõra binaarsused. Näiteks võib täheldada jõulist vastandumist äärmiselt vägivaldse ja ebainimlikuna tajutud islamiusulistele ning kõikvõimalikele sotsiaalsetele rühmadele ja institutsioonidele, kes mahuvad ähmase ühisnimetaja "valge rassi vastase genotsiidi korraldajad" alla. Antiteetiline modelleerimine aitab ühelt poolt paigutada konkreetseid sündmusi/agente kogukonna ühismälu koordinaadistikku, kuid samas kinnitab iga üksiknäide omakorda ka olemasolevaid stereotüüpe ning aitab seeläbi kaasa vastanduste radikaliseerumisele. Sellega on vahetult seotud enesessesulguva autokommunikatsiooni teine dominant, "õigetele" tekstidele orienteeritus, mis avaldub näiteks suundumuses samastuda enesekirjelduse tasandil teatud tekstidega (nt põhiseadusega, iseäranis punktiga, mis räägib rahva, kultuuri ja keele säilitamise kohustusest). Olulisel kohal on ka paralleelide tõmbamine hetkeolukorra või alles saabuvate sündmuste ja mälutekstide (nt ohvriteksti, romaani “1984" või NWO vandenõuteooria) vahel. Kajakambrisuhtluse kolmandaks dominandiks on faatilise orientatsiooniga teadete suur osakaal. Nimelt moodustab paremäärmusliku 
võrgustiku teiste sõlmekeste tegevusega kursisoleku demonstreerimine (nt linkide jagamise, autoriteetsete allikate kopeerimise või refereerimise jms) märkimisväärse osa infovahetusest. Samuti väljendub faatiline suhtlus n-ö siseringi kuulumist markeeriva leksika (nt pederallala või lillaroosa udu) vahetamises. Üldistavalt võime öelda, et märgitud kolme tunnuse kooseksisteerimisel kaotab autokommunikatiivne tähendusloome oma innovatsioonilise potentsiaali ja hakkab tootma polariseeruvat ja hermeetilist tähendust.

Peame vajalikuks rõhutada, et meie uurimuses avatud kajakambrisuhtluse üldised karakteristikud pole iseloomulikud üksnes paremäärmuslikele võrgustikele. Kahtlemata kerkib see suuremal või väiksemal määral esile mis tahes vernakulaarsetes kogukondades. Sarnast maailmavaadet vahendavate ja taastootvate infokanalite ümber koondumine on üldinimlik ning on loomulik, et akuutsete ühiskondlike probleemide arutamisel kerkib esile polariseeruv kommunikatsioon, mis suuresti välistab kokkupuute põhimõtteliselt teistlaadi vaatepunktidega. Euroopa rändekriis on kahtlemata äärmiselt tugevaid vastandusi tekitav teema ning kindlasti võib ses kontekstis täheldada ka vasakpoolseid väärtusi jagavate kogukondade sulgumise ning hermeetilise kommunikatsiooni suundumusi, kõnekaks näiteks võib tuua 2015. aasta novembris toimunud meeleavalduse, mis kandis nime "Tartu sallimatust ei salli".

Lotmani ja Uspenski sõnul on kultuuri suurimaks seesmiseks vaenlaseks märgisüsteemide kalduvus automatiseeruda ning kultuur peab selle vastu lakkamatut heitlust (Lotman \& Uspenski 2013: 228). Erinevalt kreatiivsest autokommunikatsioonist ei võimalda suletud autokommunikatsioon välisest keskkonnast tulenevatele väljakutsetele vastata ning kapseldub kommunikatsiooni edenedes üha enam olemasolevate seoste kinnistamisse. Hermeetilises suhtluses läheb suuresti kaduma juhuslike tähendusplahvatusteni jõudmise võimalus ning õppimise ja uuenemise potentsiaal. Niisuguse kajakambrikommunikatsiooni uurimine heidab valgust erinevate nišikogukondade formeerumisele ja võib aidata selgitada, miks (vaatamata interaktiivse üleilmse suhtlusvõrgustiku võimalustele) iseloomustab erinevaid vernakulaarseid kogukondi sageli oma infokookonisse kapseldumine ja suutmatus astuda dialoogi. 


\section{Kommentaarid}

1 Käesoleva artikli valmimist on toetanud IUT 2-44, PUT 44 ja "Marie Curie International Research Staff Exchange Scheme Fellowship within the 7th European Community Framework Programme (EU-PREACC project)".

2 Mitmed autorid on kasutanud mõistet translocal whiteness, mis osutab "valgete" identifikatsioonile, mis ei ole seotud spetsiifilise regiooni või rahvusega, vaid ületab geograafia dimensiooni ja on seotud globaalsete võrgustikega (Daniels 2009: 43). Euroopa paremäärmuslasi koondavas võrgusuhtluses on sellisteks n-ö rahvuse-ülesteks katusteemadeks veel euroskeptitsism (Caiani \& Kröll 2014: 13-14) ning islamofoobia (Askanius \& Mylonas 2015).

${ }^{3}$ Kokkuleppeliselt peetakse Euroopa põgenikekriisi alguseks 2015. aasta aprilli, mil Vahemerel uppus lühikese aja jooksul üle tuhande inimese. Alates aprillist käivitusid erinevad vastumeetmed, mille eesmärk oli piiride tugevdamine, inimsmuugeldamise vastu võitlemine ja põgenike kvootide alusel jaotamine erinevate EL riikide vahel (vt ka https://en.wikipedia.org/wiki/European_migrant_crisis).

4 Eestis saatsid arutelu korduvad meeleavaldused ja muud avaliku arvamuse avaldamise viisid (nt motoklubi matk Vao külla põgenikelaagrisse). Kõige tõsisema juhtumina võib osutada Vao põgenikele mõeldud maja süütamist.

5 Attoni ja Hamiltoni järgi on alternatiivsele meediale omane kriitiline suhtumine peavoolu ajakirjanduse dominatsetesse praktikatesse. See ei seostu ainult teatud teemade katmata jätmisega / katmisega, vaid ollakse seisukohal, et on olemas "alternatiive uudisteallikate ja representatsioonide konventsioonidele, elitaarsele ajakirjanduspraktikale, objektiivsuskaanonitele ning vastuvõtja mõneti mahasurutud positsioonile". Ideaalis on alternatiivne ajakirjandus väljaspoolt peavoolumeedia institutsioone ja võrgustikke. (Atton \& Hamilton 2008: 1.)

6 Postituste tsiteerimisel jätame esialgse kirjapildi muutmata.

7 http://koobas.net/2015/04/17/repressiivne-sundsallivus/ - ei ole enam kättesaadav, dubleeritud http://rahvuslane.blogspot.com.ee/2015/04/koobas-repressiivne-sundsallivus. html; http://rahvuslane.blogspot.com.ee/2015/04/matti-ilves-tulistamisest-rootsis-ja.html; http://rahvuslane.blogspot.com.ee/2015/10/anti-poolamets-juku-kalle-raid-avaldas.html.

8 http://rahvuslane.blogspot.com.ee/2015/06/jaan-hatto-enesehavituse-ilu.html; http:// rahvuslane.blogspot.com.ee/2015/07/juri-kukk-eestimaa-anno-domini-2030.html; http://rahvuslik.blogspot.com/2015/03/je-suis-ekre-sona-ja-mottevabaduse-ning.html ei ole enam kättesaadav, dubleeritud http://rahvuslane.blogspot.com.ee/2015/04/jesuis-ekre-sona-ja-mottevabaduse-ning.html.

9 http://rahvuslane.blogspot.com.ee/2015/06/raivo-orgusaar-vastuseis-eesti.html; http:// rahvuslane.blogspot.com.ee/2015/06/matti-ilves-on-alustatud-eesti.html; http:// rahvuslane.blogspot.com.ee/2015/04/helme-tegelikult-pole-eestis-mingit.html.

$10 \mathrm{http} / / /$ rahvuslane.blogspot.com.ee/2015/11/mis-sunnitab-breivikuid-dialoogi.html; http://rahvuslik.blogspot.com.ee/2015/09/peavooluajakirjandus-eriti-delfi-ohutab. html\#more - ei ole enam kättesaadav; http://rahvuslane.blogspot.com.ee/2015/09/ peavooluajakirjandus-eriti-delfi-ohutab.html.

${ }^{11} \mathrm{http} / / /$ rahvuslane.blogspot.com.ee/2015/04/mart-helme-vaadake-toele-silma-arge.html; http://rahvuslik.blogspot.com/2015/06/pole-vahet-kas-rahvas-havitatakse.html\#more blogi Rahvuslik ei ole enam kättesaadav, postitus on dubleeritud http://rahvuslane. blogspot.com.ee/2015/06/pole-vahet-kas-rahvas-havitatakse.html. 
12 On tähelepanuväärne, et varasemate (2012-2014) vaatluste kontekstis oli eesti paremäärmuslikus võrgustikus islamofoobse sisu osakaal väga väike, viimasel ajal on sellest aga saanud oluline dominant. Võib täheldada islamofoobsete ideede importimist Skandinaavia päritolu paremäärmuslikelt veebilehekülgedelt, muuhulgas leidub viiteid Breiviki manifestile ja Eurabia kontseptsioonile.

${ }^{13}$ http://bhruzzland.balanss.ee/toeline-islam; vt ka http://bhruzzland.balanss.ee/ naabrid/891-luehidalt-07-12-2015-taeiendatav.

${ }^{14} \mathrm{http} / / /$ rahvuslane.blogspot.com.ee/2015/11/pagulased-kui-terroristide-inimkilp.html.

${ }^{15} \mathrm{http}$ ///rahvuslane.blogspot.com.ee/2015/06/allan-sarri-mis-kuradi-transseksuaal.html.

${ }^{16} \mathrm{http}$ ://rahvuslane.blogspot.com.ee/2015/10/matti-ilves-euroopa-liit-peab-vastu.html.

${ }^{17}$ http://rahvuslik.blogspot.com/2015/06/pole-vahet-kas-rahvas-havitatakse.html\#moreei ole enam kättesaadav, kuid on dubleeritud http://rahvuslane.blogspot.com. ee/2015/06/pole-vahet-kas-rahvas-havitatakse.html.

${ }^{18} \mathrm{http}$ ://rahvuslik.blogspot.com/2015/03/je-suis-ekre-sona-ja-mottevabaduse-ning. html - ei ole enam kättesaadav, kuid on dubleeritud http://rahvuslane.blogspot.com. ee/2015/04/je-suis-ekre-sona-ja-mottevabaduse-ning.html.

${ }^{19} \mathrm{http}$ ://rahvuslik.blogspot.com.ee/2015/10/eesti-on-muudetud-politseiriigiks-kus. html - ei ole enam kättesaadav, kuid on dubleeritud http://rahvuslane.blogspot.com. ee/2015/10/eesti-on-muudetud-politseiriigiks-kus.html.

${ }^{20} \mathrm{http}$ ://rahvuslik.blogspot.com/2015/06/pole-vahet-kas-rahvas-havitatakse. html\#more - ei ole enam kättesaadav, kuid on dubleeritud http://rahvuslane.blogspot. com.ee/2015/06/pole-vahet-kas-rahvas-havitatakse.html.

${ }^{21} \mathrm{http}$ ///rahvuslik.blogspot.com/2015/03/je-suis-ekre-sona-ja-mottevabaduse-ning. html - ei ole enam kättesaadav, kuid on dubleeritud http://rahvuslane.blogspot.com. ee/2015/04/je-suis-ekre-sona-ja-mottevabaduse-ning.html.

${ }^{22} \mathrm{http} / / /$ koobas.net/2015/04/03/teretulemast-rootsi/ - ei ole enam kättesaadav, kuid on dubleeritud http://rahvuslane.blogspot.com.ee/2015/04/koobas-teretulemast-rootsi. html.

${ }^{23} \mathrm{http} / / /$ rahvuslik.blogspot.com/2015/03/je-suis-ekre-sona-ja-mottevabaduse-ning.html ei ole enam kättesaadav; http://bhruzzland.balanss.ee/isamaa/ensv-ev/437-euroopaliitu-ei-huvita-tartu-rahuleping-ega-meie-riiklik-vaeaerikus.

${ }^{24} \mathrm{http}$ ://rahvuslane.blogspot.com.ee/2015/05/kivisildnik-valitsus-vahetab-rahva.html.

${ }^{25} \mathrm{http}$ ://rahvuslane.blogspot.com.ee/2015/05/kivisildnik-mis-on-meile-kasulikum-kas. html.

${ }^{26} \mathrm{http} / / /$ rahvuslik.blogspot.com/2015/06/pole-vahet-kas-rahvas-havitatakse.html\#moreei ole enam kättesaadav, dubleeritud http://rahvuslane.blogspot.com.ee/2015/06/polevahet-kas-rahvas-havitatakse.html.

${ }^{27} \mathrm{http} / / /$ rahvuslane.blogspot.com.ee/2015/09/matti-ilves-laanes-levib-intellektaalne. html.

${ }^{28} \mathrm{http} / / /$ rahvuslane.blogspot.com.ee/2015/06/jaan-hatto-enesehavituse-ilu.html.

${ }^{29} \mathrm{http}$ ///rahvuslane.blogspot.com.ee/2015/11/pagulased-kui-terroristide-inimkilp.html.

${ }^{30} \mathrm{http}$ ://rahvuslane.blogspot.com.ee/2015/05/kivisildnik-valitsus-vahetab-rahva.html. 
${ }^{31} \mathrm{http} / / /$ rahvuslane.blogspot.com.ee/2015/05/toomas-roosileht-eesti-rahvusel-on.html; http://rahvuslane.blogspot.com.ee/2015/10/anti-poolamets-juku-kalle-raid-avaldas. html; http://rahvuslik.blogspot.com/2015/08/pagulasprobleemi-reaalne-lahendus. html\#more - ei ole enam kättesaadav, dubleeritud http://rahvuslane.blogspot.com. ee/2015/08/pagulasprobleemi-reaalne-lahendus.html.

${ }^{32}$ http://rahvuslane.blogspot.com.ee/2015/06/jaan-hatto-enesehavituse-ilu.html; http:// rahvuslane.blogspot.com.ee/2015/06/norras-ei-ole-koik-korras-97.html.

${ }^{33} \mathrm{http}: / /$ bhruzzland.balanss.ee/toeline-islam; http://bhruzzland.balanss.ee/naabrid/891luehidalt-07-12-2015-taeiendatav.

${ }^{34} \mathrm{http}$ ///rahvuslane.blogspot.com.ee/2015/04/koobas-miks-nn-pogenikud-ei-lahe.html.

${ }^{35} \mathrm{http} / / /$ rahvuslane.blogspot.com.ee/2015/08/pagulaste-monus-elu-saksamaal.html.

${ }^{36} \mathrm{http} / / /$ rahvuslane.blogspot.com.ee/2015/06/rahvas-andis-roivase-kabinetile-selge.html.

${ }^{37}$ Sugugi vähem tähtsaks ei saa pidada teksti funktsiooni, mis seostub kollektiivse mälu kindlustamisega, kollektiivi muutmisega stiihilisest massist ühtseks persooniks (Une personne morale) (Lotman 2006: 244).

${ }^{38} \mathrm{http}$ ///rahvuslane.blogspot.com.ee/2015/11/matti-ilves-legaliseeritakse-valgete.html.

${ }^{39} \mathrm{http} / / /$ rahvuslane.blogspot.com.ee/2015/06/jaan-hatto-enesehavituse-ilu.html.

${ }^{40} \mathrm{http} / / /$ rahvuslane.blogspot.com.ee/2015/10/lahendused-on-olemas-lahendused-on.html.

${ }^{41} \mathrm{http} / / /$ rahvuslik.blogspot.com.ee/2015/11/mis-sunnitas-breiviku-dialoogi.html\#more ei ole enam kättesaadav, seda on kasutatud http://rahvuslane.blogspot.com.ee/2015/11/ mis-sunnitab-breivikuid-dialoogi.html.

${ }^{42}$ http://rahvuslane.blogspot.com.ee/2015/09/kivisildnik-sotsialistliku.html, vahel osutatakse sellele ka kui lihtsalt roosale udule.

${ }^{43}$ Meie artikli kontekstis osutab see tähenduslike seoste süvenemisele.

${ }^{44}$ Kuigi Jakobson tegeles peamiselt lingvistika näidetega, rõhutas ta, et tema sihiks on pragmaatilise keelekäsitluse loomine, mis võiks olla aluseks ka teiste semiootiliste süsteemide vahendusel toimuva kommunikatsiooni funktsionaalseks uurimiseks (Jakobson 1971b: 703).

${ }^{45} \mathrm{http}$ ://rahvuslane.blogspot.com.ee/2015/11/mis-sunnitab-breivikuid-dialoogi.html.

${ }^{46} \mathrm{http}$ ://rahvuslane.blogspot.com.ee/2015/10/white-race-genocide-valge-rassi.html.

${ }^{47} \mathrm{http}$ ://rahvuslane.blogspot.com.ee/2015/08/getter-suup-moslemipogenike-vastuvott. html.

${ }^{48}$ http://rahvuslane.blogspot.com.ee/2015/06/laupaevased-pildid_27.html.

${ }^{49} \mathrm{http} / / /$ rahvuslane.blogspot.com.ee/2015/12/heldur-paulson-immigrantidest-ja_2.html.

50 88-tähendab "Heil Hitler" ning tähistusviis on tingitud sellest, et $\mathrm{H}$ on tähestiku kaheksas täht.

${ }^{51}$ RAHOWA on lühend väljendist Racial Holy War ehk püha rassisõda.

${ }^{52}$ PWA on lühend väljendist Preserve White Aryans ehk säilitage valged aarialased, P.W.A. on ka eesti skinheadide punkbändi nimi. 


\section{Allikad}

\section{Eesti paremäärmuslikud blogid:}

BH RuZZland - http://bhruzzland.balanss.ee/ (6. veebruar 2018).

Koobas - http://koobas.net (ei ole enam kättesaadav, kuid postitused on dubleeritud blogis Rahvuslane).

Rahvuslane - http://rahvuslane.blogspot.com.ee (6. veebruar 2018).

Rahvuslik blogi - http://rahvuslik.blogspot.com.ee (ei ole enam kättesaadav, kuid postitused on dubleeritud blogis Rahvuslane).

\section{Kirjandus}

Askanius, Tina \& Mylonas, Yiannis 2015. Extreme-right Responses to the European Economic Crisis in Denmark and Sweden: The Discursive Construction of Scapegoats and Lodestars. Javnost: The Public 22 (1), lk 55-72 (doi: 10.1080/13183222.2015.1017249).

Atton, Chris 2006. Far-right media on the internet: culture, discourse and power. New media \& society 8 (4), lk 573-587 (doi: 10.1177/1461444806065653).

Atton, Chris \& Hamilton James F. 2008. Alternative journalism. Journalism Studies: Key Texts. Sage: London.

Back, Les 2002. Aryans reading Adorno: cyber-culture and twenty-firstcentury racism. Ethnic and Racial Studies 25 (4), lk 628-651 (doi: 10.1080/01419870220136664).

Caiani, Manuela \& Kröll, Patricia 2014. The transnationalization of the extreme right and the use of the Internet. International Journal of Comparative and Applied Criminal Justice, lk 1-21 (doi: 10.1080/01924036.2014.973050).

Cammaerts, Bart 2007. Jamming the Political: Beyond Counter-hegemonic Practices, Continuum. Journal of Media and Cultural Studies 21 (1), lk 71-90 (doi: 10.1080/10304310601103992).

Chadwick, Andrew 2009. Web 2.0: New challenges for the study of e-democracy in an era of informational exuberance. Journal of Law and Policy for the Information Society 5 (1), lk 10-42.

Daniels, Jessie 2009. Cyber Racism: White Supremacy Online and the New Attack on Civil Rights: Perspectives on a Multiracial America. Plymouth: Rowman \& Littlefield Publishers.

Daniels, Jessie 2012. Race and racism in Internet studies: A review and critique. New Media \& Society 10, lk 1-25 (doi: 10.1177/1461444812462849).

Downey, John \& Fenton, Natalie 2003. New Media, Counter Publicity and the Public Sphere. New Media \& Society 5 (2), lk 185-202 (doi: 10.1177/1461444803005002003). 
Eco, Umberto 1990. Interpretation and Overinterpretation. World, History, Texts. The Tanner Lectures on Human Values. Cambridge: Cambridge University (https://tannerlectures.utah.edu/_documents/a-to-z/e/Eco_91.pdf - 7. veebruar 2018).

Eco, Umberto 1995. Igikestev fašism. Vikerkaar 9 (10), lk 65-75 (http://www.vikerkaar. ee/archives/14272 - 7. veebruar 2018).

Gradinaru, Camelia 2013. From Multitude to Convergence: Contemporary Trends in the Study of Online Identity. Argumentum: Journal the Seminar of Discursive Logic, Argumentation Theory \& Rhetoric, lk 95-108.

Griffin, Roger 2011. Limaseenest risoomini: sissejuhatus grupuskulaarsesse parempoolsusesse. Vikerkaar 9, lk 53-77 (http://www.vikerkaar.ee/archives/12711 - 7. veebruar 2018).

Grumke, Thomas 2013. Globalized anti-globalists: The ideological basis of the internationalization of right-wing extremism. Von Mering, Sabine \& McCarty, Timothy Wyman (toim). Right-wing radicalism today: Perspectives from Europe and the US. London: Routledge, lk 13-22.

Grömping, Max 2014. Echo Chambers: Partisan Facebook Groups during the 2014 Thai Election. Asia Pacific Media Educator 24 (1), lk 39-59.

Hale, Chris 2012. Extremism on the World Wide Web: a research review. Criminal Justice Studies 25 (4), lk 343-356.

Han, Lei 2014. Juri Lotman's autocommunication model and Roland Barthes's representations of Self and Other. Sign Systems Studies 42 (4), lk 517-529 (doi: 10.12697/ SSS.2014.42.4.05).

Hartley, John 2014. Urban semiosis: Creative industries and the clash of systems. International Journal of Cultural Studies, lk 1-23 (doi: 10.1177/1367877914528120).

Hirvonen, Katarina 2013. Sweden: when hate becomes the norm. Race \& Class 55 (1), lk 78-86 (doi: 10.1177/0306396813486604).

Howard, Robert Glenn. 2011. Digital Jesus: The Making of a New Christian Fundamentalist Community on the Internet. New York: New York University Press.

Howard, Robert Glenn 2013. Vernacular Authority: Critically Engaging "Tradition". Blank, Trevor J. \& Howard, Robert Glenn (toim). Tradition in the Twenty-First Century. Locating the Role of the Past in the Present. Boulder, Colorado: Utah State University Press, lk 72-99.

Ibrus, Indrek 2010. Evolutionary dynamics of new media forms: the case of the open mobile web. PhD thesis. London: The London School of Economics and Political Science (LSE).

Ibrus, Indrek \& Torop, Peeter 2015. Remembering and reinventing Juri Lotman for the digital age. International Journal of Cultural Studies 18 (1), lk 3-9 (doi: 10.1177/1367877914528113).

Ivanov, Vladimir \& Toporov, Vladimir \& Pjatigorskij, Aleksander \& Lotman, Juri \& Uspenskij, Boris 1998. Tezisy k semioticheskomu izucheniiu kul'tur (v primenenii $k$ slavianskim tekstam) $=$ Theses on the Semiotic Study of Cultures (As Applied to the Slavic Texts) = Kultuurisemiootika teesid (slaavi tekstidest lähtuvalt). Tartu Semiotics Library 
1. Tartu: Tartu University Press (http://dspace.ut.ee/bitstream/handle/10062/54550/ theses_on_the_semiotic_ocr.pdf? sequence=1\&isAllowed=y - 7. veebruar 2018).

Jakobson, Mari-Liis \& Balcere, Ilze \& Loone, Oudekki \& Nurk, Anu \& Saarts, Tõnis \& Zakeviciute, Rasa 2012. Populism in the Baltic States: A Research Report. Tallinn University Institute of Political Science and Governance, Open Estonia.

Jakobson, Roman 1971a. Dominant. Matejka, Ladislav \& Pomorska, Krystyna (toim). Readings in Russian Poetics: Formalist and Structuralist Views. Cambridge, Mass.: MIT Press, lk 82-87.

Jakobson, Roman 1971b. Language in Relation to Other Communication Systems. Selected Writings II: Word and Language. The Hague \& Paris: Mouton, lk 697-708.

Jakobson, Roman 1976. Metalanguage as a linguistic problem. Selected Writings VII. The Hague: Mouton, lk 113-121.

Jamieson, Kathleen Hall \& Cappella, Joseph N. 2008. Echo chamber: Rush Limbaugh and the conservative media establishment. Oxford, New York: Oxford University Press.

Kallio, Tomi J. \& Sandström, Johan 2009. Academic writing as autocommunication - the case of doctoral dissertations on CSR. Culture and Organization 15 (1), lk 75-87 (doi: 10.1080/14759550802709566).

Kushin, Matthew J. \& Kitchener, Kelin 2009. Getting political on social network sites: Exploring online political discourse on Facebook. First Monday 14 (11), lk 1-16 (doi: 10.5210/fm.v14i11.2645).

Laver, John 1975. Communicative functions of phatic communion. Kendon, Adam \& Harris, Richard M. \& Key, Mary R. (toim). Organization of Behaviour in Face-toFace Interaction. The Hague: Mouton, lk 215-238.

Lepik, Peet 2007. Universaalidest Juri Lotmani semiootika kontekstis. Tartu Semiotics Library. Tartu Ülikooli Kirjastus.

Lindström, Kati 2010. Autocommunication and Perceptual Markers in Landscape: Japanese Examples. Biosemiotics 3, lk 359-373 (doi: 10.1007/s12304-010-9082-0).

Lotman, Juri 1999a. Semiosfäärist. Semiosfäärist. Tallinn: Vagabund, lk 7-36.

Lotman, Juri 1999b. Kultuur kui subjekt ja iseenese objekt. Semiosfäärist. Tallinn: Vagabund, lk 37-52.

Lotman, Juri 2002a. Kultuuri fenomen. Akadeemia 12, lk 2644-2662.

Lotman, Juri 2002b = Lotman, Iu. M. Tekct i struktura auditorii. Istoriia i tipologiia russkoi kul'tury. Sankt-Peterburg: Isskustvo, lk 169-174.

Lotman, Juri 2006. Retoorika. Kultuurisemiootika. Tekst-kirjandus - kultuur. Tallinn: Olion, lk 186-211.

Lotman, Juri 2007. Nõiajaht. Hirmu semiootika. Lotman, Mihhail (koost). Hirm ja segadus: Esseid kultuurisemiootikast. Tallinn: Varrak, lk 50-68.

Lotman, Juri 2009. Culture and Explosion. Berlin \& New York: De Gruyter. 
Lotman, Juri 2010a. 'Kultuuri õpetamise' probleem kui tüpoloogiline karakteristik. Salupere, Silvi (toim). Kultuuritüpoloogiast. Tartu: Tartu Ülikooli Kirjastus, lk 60-80 (http://lepo.it.da.ut.ee/ silvi11/Lotman-sisu-trykki.pdf - 6. veebruar 2018).

Lotman, Juri 2010b. Kahest kommunikatsioonimudelist kultuurisüsteemis. Salupere, Silvi (toim). Kultuuritüpoloogiast. Tartu: Tartu Ülikooli Kirjastus, lk 127-148 (http:// lepo.it.da.ut.ee/ silvi11/Lotman-sisu-trykki.pdf - 6. veebruar 2018).

Lotman, Juri 2010c. Märgi ja märgisüstemide probleem ja vene kultuuri tüpoloogia XI-XIX sajandil. Salupere, Silvi (toim). Kultuuritüpoloogiast. Tartu: Tartu Ülikooli Kirjastus, lk 36-72 (http://lepo.it.da.ut.ee/ silvi11/Lotman-sisu-trykki.pdf - 6. veebruar 2018).

Lotman, Juri \& Uspenski, Boriss 2013. Kultuuri semiootilisest mehhanismist. Uspenski, Boriss \& Lepik, Peet (koost). Vene kultuuri jõujooni. Valik artikleid. Tartu: Ilmamaa, lk 207-239.

Madisson, Mari-Liis 2016. NWO conspiracy theory: A key frame in online communication of Estonian extreme right. Lexia. Rivista di semiotica 23-24, lk 189-208 (doi: 10.4399/978885489931511).

Madisson, Mari-Liis \& Ventsel, Andreas 2012 Võõra semiootiline modelleerimine Eesti lähiajaloos. Acta Semiotica Estica IX, lk 144-172.

Madisson, Mari-Liis \& Ventsel, Andreas 2014. Paremäärmuslik sõnavabadus eesti rahvusradikaalide veebisuhtluses. Mäetagused 57, lk 69-90 (doi: 10.7592/MT2014.57. madisson_ventsel).

Madisson, Mari-Liis \& Ventsel, Andreas 2015. Grupuskulaarne identiteediloome eesti paremäärmuslaste võrgusuhtluses. Methis 15, lk 8-28 (doi: 10.7592/methis.v12i15.12113).

O'Callaghan, Derek \& Greene, Derek \& Conway, Maura \& Carthy, Joe \& Cunningham, Padraig 2013. The Extreme Right Filter Bubble (http://arxiv.org/abs/1308.6149 7. veebruar 2018).

O'Callaghan, Derek \& Greene, Derek \& Conway, Maura \& Carthy, Joe \& Cunningham, Padraig 2015. Down the (White) Rabbit Hole: The Extreme Right and Online Recommender Systems. Social Science Computer Review 33 (4), lk 459-478 (doi: 10.1177/0894439314555329).

Ojamaa, Maarja \& Torop, Peeter 2015. Transmediality of cultural autocommunication. International Journal of Cultural Studies 18 (1), lk 61-78.

Radovanovic, Danica \& Ragnedda, Massimo 2012. Small talk in the Digital Age: Making Sense of Phatic Posts. \#MSM2012 2nd Workshop on Making Sense of Microposts, lk 10-13.

Randviir, Anti 2018. Sotsiosemiootika. Salupere, Silvi \& Kull, Kalevi (toim). Semiootika. Tartu: Tartu Ülikooli Kirjastus, lk 230-251.

Rydgren, Jens 2004. Radical Right-Wing Populism in Sweden and Denmark. The Centre for the Study of European Politics and Society (https://www.researchgate.net/ publication/236803141_Radical_Right-wing_Populism_in_Denmark_and_Sweden_ Explaining_Party_System_Change_and_Stability - 7. veebruar 2018). 
Schönle, Andreas 2002. Lotman and cultural studies: The case for cross-fertilization. Sign Systems Studies 30 (2), lk 429-440.

Siibak, Andra 2012. Changes in the user practices: the case of extreme nationalist users of SNS Rate. Social Media: Risks and Opportunities in Military Applications. Tallinn: The Research and Technology Organisation of NATO.

Siibak Andra 2014. Being Publicly Private: Extreme Nationalist User Practices on Social Networks. Security in Cyberspace: Targeting Nations, Infrastructures, Individuals. Giacomello \& London \& New York: Bloomsbury, lk 215-230 (http://www.academia. edu/10299069/Being_Publicly_Private_Extreme_Nationalist_User_Practices_on_Social_ Networks - 7. veebruar 2018).

Simi, Pete \& Futrell, Robert 2006. Cyberculture and the endurance of white power activism. Journal of Political \& Military Sociology 34 (1), lk 115-142.

Stroud, Natalie Jomini 2010. Polarization and Partisan Selective Exposure. Journal of Communication 60, lk 556-576 (doi: 10.1111/j.1460-2466.2010.01497.x).

Sunstein, Cass R. 2009. Going to Extremes: How Like Minds Unite and Divide. Oxford, New York: Oxford University Press.

Torop, Peeter 2008. Multimeedialisus. Keel ja Kirjandus 8-9, lk 721-734 (https:// keeljakirjandus.eki.ee/721-734.pdf - 7. veebruar 2018).

Torop, Peeter 2013. Autokommunikatsioon ja identiteet. Vikerkaar 28 (1-2), lk 123-133.

Tufekci, Zeynep 2008. Grooming, gossip, Facebook and MySpace. What can we learn about these sites from those who won't assimilate? Information, Communication \& Society 11 (4), lk 544-564 (doi: 10.1080/13691180801999050).

Van Alstyne, Marshall \& Brynjolfsson, Erik 2005. Global village or cyber-Balkans? Modeling and measuring the integration of electronic communities. Management Science 51 (6), lk 851-868 (doi: 10.1287/mnsc.1050.0363).

Ventsel, Andreas \& Raudsepp, Maaris 2015. Sotsiaalsete süsteemide võim ja semiootilise subjekti autonoomia. Akadeemia 4, lk 651-687 (http://www.academia.edu/18132463/So tsiaalsete_s\%C3\%BCsteemide_v\%C3\%B5im_ja_semiootiline_autonoomia._Akadeemia_ IV_651_-_688._2015 - 7. veebruar 2018).

Ventsel, Andreas 2016. Political potentiality of conspiracy theories. Lexia. Journal of Semiotics 23-24, lk 217-234.

Wojcieszak, Magdalena 2010. 'Don't talk to me': effects of ideologically homogeneous online groups and politically dissimilar offline ties on extremism. New Media \& Society 12 (4), lk 637-655 (doi: 10.1177/1461444809342775).

Wojcieszak, Magdalena \& Price, Vincent 2010. Bridging the Divide or Intensifying the Conflict? How Disagreement Affects Strong Predilections about Sexual Minorities. Political Psychology 31 (3), lk 315-339 (doi: 10.1111/j.1467-9221.2009.00753.x). 


\section{Summary}

\section{Extreme right echo-chambers and auto-communication}

\section{Mari-Liis Madisson}

Research Fellow, Institute of Philosophy and Semiotics

Junior Research Fellow of cultural communication, Institute of Social Studies

University of Tartu, Estonia

ml.madisson@gmail.com

\section{Andreas Ventsel}

Senior Research Fellow

Institute of Philosophy and Semiotics

University of Tartu, Estonia

andreas.ventsel@gmail.com

Keywords: auto-communication, echo-chamber effect, extreme right online communication in Estonia, phatic communication, refugee crisis of 2015, semiotics of culture

This paper concentrates on the online communication of the Estonian extreme right that seems to be characterized by an echo-chamber effect and enclosed meaning-making. The discussion mainly relies on the theoretical frameworks based on semiotics of culture.

One of the goals of the study is to widen the scope of understanding of auto-communicative processes that are usually related to learning, insight, and innovation. The paper demonstrates the conditions in which auto-communicative processes result in closed interactions, based on reproducing stereotypes and redundant content. We explicate antithetical meaning-making, an orientation towards normative ("correct") texts and the prevalence of phatic communication as the main dominants that guide the closed auto-communication. Our case study is about the discussion that emerged in the context of the European refugee crisis that started in spring 2015. 